NBER WORKING PAPER SERIES

\author{
OPTIMAL TAXATION OF HUMAN \\ AND PHYSICAL CAPITAL IN \\ ENDOGENOUS GROWTH MODELS
}

\author{
Nouriel Roubini \\ Gian Maria Milesi-Ferretti
}

Working Paper No. 4882
NATIONAL BUREAU OF ECONOMIC RESEARCH 1050 Massachusetts Avenue
Cambridge, MA 02138
October 1994

\begin{abstract}
This project started while Nouriel Roubini was visiting the Research and Fiscal Affairs Departments at the International Monetary Fund. We are grateful to Nick Bull for extensive discussions, and to Willem Buiter, Giancarlo Corsetti, Jean-Michel Grandmont, Se-Jik Kim, Ken Kletzer, Enrique Mendoza, Assaf Razin, T.N. Srinivasan and Philippe Weil and seminar participants at the International Monetary Fund, Brown University, Yale, Harvard and Université Libre de Bruxelles for useful suggestions. This paper is part of NBER's research programs in Intemational Finance and Macroeconomics and Public Economics. Any opinions expressed are those of the authors and not those of the International Monetary Fund or the National Bureau of Economic Research.
\end{abstract}

(C) 1994 by Nouriel Roubini and Gian Maria Milesi-Ferretti. All rights reserved. Short sections of text, not to exceed two paragraphs, may be quoted without explicit permission provided that full credit, including (C) notice, is given to the source. 


\title{
OPTIMAL TAXATION OF HUMAN \\ AND PHYSICAL CAPITAL IN \\ ENDOGENOUS GROWTH MODELS
}

\begin{abstract}
This paper studies the effects of human and physical capital income taxation on growth, and examines how these effects depend on the technologies for human capital accumulation and "leisure". It then derives the normative implications of the analysis for the optimal taxation of factor incomes. It is shown that in general both capital and labor (human capital) taxes are growth-reducing. In these cases, the optimal long-run tax on both capital and labor income is zero. The optimal taxation plan consists of taxing both factors in the short run, and financing spending in the long run through accumulated budget surpluses.
\end{abstract}

Nouriel Roubini

Deparment of Economics

Yale University

PO Box 208268

New Haven, CT 06520-8268

and NBER
Gian Maria Milesi-Ferretti

Research Department

International Monetary Fund

700 19th Street, NW

Washington, DC 2043 ! 


\section{INTRODUCTION}

Traditionally, optimal taxation has been studied using models in which the growth rate of the economy is determined by exogenous factors. In such models, tax distortions affect the allocation of resources and the long-run level of per capita income. When the growth rate of the sconomy is endogenously determined, however, tax distortions may affect not only the level of per capita income, but also its growth rate. This paper studies the optimal taxation of human and physical capital in such a context.

Initial contributions on optimal dynamic factor taxation considered infinite-horizon exogenous growth models with a representative agent deriving utility from consumption of final goods and leisure time. Chamley $(1985,1986)$ and Judd (1985) showed that, in such models, the optimal tax rate on capital income is zero in the long run. Given an exogenous stream of public expenditures, in the shor run the optimal tax program requires positive tax rates on both labor and capital income, since both factors are in semi-fixed supply. In the long run, however, capital income tax rates discourage capital accumulation; expenditures should be financed only with taxes on labor income since labor/leisure (i.e. the individual's (ime endowment) is the only factor in fixed supply.

The Chamlcy-Judd results about the asymmetric long run taxation of labor and capital might be significantly modified when human capital is considered as an additional factur of production. If labor (human capital) is modeled as a reproducible factor and a source of accumulation and growth, it might be optimal to tax both labor and capital income in a similar way. Lucas (1990) shows that the result about the zero long-run taxation of capital income is not modified even when tuman capital accumulation is the source of long-nun growth. He also shows that when the time dcvoted 10 liuman capital accumulation is exogenous, the Chamley-Judd result is obtained again - all long-run taxation should fall on labor income. However, he does not derive the implications of his model for the uptimal long run taxation of labor income when the accumulation of human capital is endogenous.

A number of recent papers (Bull 1993a, 1993b and Jones, Manuelli and Rossi 1993a, 1993b) have started to address this issue.' These papers show that there are conditions under which the optimal taxation of both capital and labor income is zero in the long run. This implies that taxation on both factors must be high enuugh in the short run so as to accumulate government assets whose returns will finance long-run government spending. The simplest case where this result is obtained is the following

\footnotetext{
'A number of other contributions do not directly consider the optimal taxation of factor incomes but study the effec1s of exogenous changes in tax rates on the growth rate of the economy and the welfare of the representative agent. These contributions include Rebelo (1991), King and Rebelo (1990), Stokey and Rebelo (1993) and Trostel (1993).
} 
one. Suppose that agents derive utility from the consumption of final goods and from leisure, an activity that uses only "raw time" as input. Moreover, assume that human and physical capital are market goods that arc both perfectly substitutable with consumption and accumulated through savings (Bull 1993a and the first model in Jones, Manuelli and Rossi 1993a). In this case there is nothing peculiar about human capial: it is just a second capital good that is reproducible with the same technology as physical capital. Therefore, the optimality of the zero long nun taxation of capital income applies to both capital factors, human and physical.

Assuming that human and physical capital are perfectly symmetric is, however, restrictive. Indeed, they differ in at least three dimensions: (1) human capital is not substitutable with consumption; (2) it is a non-market good; and (3) its accumulation depends on a production function with inputs possibly different from those entering in the production of final goods and physical capital.

Concerning point (1), while most growth models specify physical capital as being perfectly substitutable with consumption -- final goods can either be consumed or accumulated in physical capital - it is more realistic to assume that human capital cannot be consumed (we can consume cars instead of using them to produce final goods but we cannot "consume our brain").

Concerning point (2), human capital accumulation should be thought as a non-market activity whose inputs are not subject to factor income taxation. Specifically, while the labor income deriving from the time spent in the production of final goods can be taxed, the time input (and implicit labor income) used in production of human capital is usually not taxed.

Concerning point (3), the production technology for human capital accumulation may use different inputs and/or have different capital intensity relative to the production technology for final goods. For example, Lucas $(1988,1990)$ assumes that human capital is a non-market good whose accumulation has only human capital (or effective labor, i.e. a time fraction of human capital) as its input. Rebelo (1991) and Mulligan and Sala-i-Martin (1993) consider instead two-sector models where human capital is produced using both human and physical capital, with factor intensities possibly different from those for the production of final goods/physical capital, but do not study optimal taxation issues. Jones, Manuelli and Rossi (1993a, 1993b) consider models where human capital is a non-market good that is produced with effective human capital and a flow of market goods, but no direct physical capital input. ${ }^{2}$ They show that, if human capital is accumulated with constant returns to its reproducible inputs (human capital

\footnotetext{
2 This specification of the human capital accumulation goes back to Ben Porath (1967) and has been used recently by Trostel (1993) as well.
} 
and market goods), both capital and labor income taxes should be zero in the long run. Bull (1993a) argues that this result is obtained also in a two-sector model in which human capital can be "produced" using physical capital, human capital and intermediate goods as inputs, and/or accumulated through learning-by-doing in the final goods' sector.

Another interesting issue concerns the specification of the leisure good. In all recent models of optimal factor taxation (Lucas 1990, Jones, Manuelli and Rossi 1993a, $1993 \mathrm{~b}$ and Bull 1993a, 1993b), leisure is considered as a non-market good that requires the use of "raw time" only. An older literature, however, considered.leisure as a more complex non-market activity requiring the use of both human and physical capital inputs, in addition to raw time. For example, in Becker (1965) and Heckman (1976) leisure is modeled as "quality time", defined as human capital times the fraction of the time endowment that is not spent working or accumulating human capital.$^{3}$ Extending this idea of leisure as being quality time, Greenurood and Hercowitz (1991) model leisure as a form of "home production" that uses effective labor and effective physical capital in its production. Indeed, most forris of leisure require the use of capital goods (think of video-stereo entertainment, sporting equipment and so on).

The discussion above suggests that the way the production technologies for human capital and leisure are specified may have important implications for the optimal taxation of factor incomes. This paper extends the analysis of Jones, Manuelli and Rossi (1993a, 1993b) and Bull (1993a) by examining the role of such technologies. We assume that both human and physical capital can enter in the production of new human capital. We are therefore able to analyze whether and how the direct inclusion of physical capital inputs in the production of human capital affects the results about the optimal long run taxation of factor incomes. We also study the implications of alternative specifications of leisure production for the optimal factor taxation results. Our specification of the leisure function is quite general and includes as sub-cases the conventional "raw time" specification, the "quality time" model, the "home

${ }^{3}$ Suppose that $w_{1}$ and $z_{l}$ are the fractions of the time endowment spent working and accumulating buman capital respectively; then leisure is defined as $L_{1}=\left(1-u_{1}-z_{1}\right) H_{3}$, where $H$ is the stock of human capital. See Rebelo (1791) for such a formulation of leisure as "effective labor" in an endogenous growth model.

- Tanzi and Zee (1993) go even further in blurring the distiaction between consumption of final gonds and leisure by modelling consumption as an activity that always requires the use of time (in a fixed proportion technology in their model). Benhabib, Rogerson and Wright (1991) distinguish "home production" from leisare, and model the latter as raw time.

S See Rebelo (1991) and Mulligan and Sala-i-Martin (1993) for similar specifications of the human capital accumulation equation. Our formulation includes, as subcases, the specification a la Lucas (1990) where only effective labor enters in the production of human capital. 
production" model, and the case of no leisure. ${ }^{6}$ We restrict our attention to models in which economic grr wth is endogenous and that have a balanced growth path.

Our main results, summarized in Table $\mathrm{I}$, are as follows:

(1) If the leisure process is specified as "raw time" - or, more generally, if leisure is not produced with constant returns to reproducible factors - the steady state growth rate of the economy is a finction of both the tax rate on labor and capital income regardless of the way human capital is accumulated. This dependence of the steady state growth rate on both tax rates implies that the optimal tax on both human and physical capital should be zero in the long run. Lucas (1990) used this specification of leisure to show that the optimal long-run tax on capital income is zero, but did not formally study or derive the optimal tax on labor income. A full solution of his model shows, however, that both factor income taxes should be zero in the long run,

(2) The steady-state growth rate of the economy in models with no leisure is qualitatively similar to that in models where the leisure activity is modeled as "quality time" or "home production". This is because in the last two cases leisure is a non-market activity produced with constant returns to scale to reproducible factors, and can therefore be reinterpreted as a non-market consumption good.

(3) Under the three specifications for leisure described above (no leisure, quality time and home production), the human capital accumulation function has important implications for the dependence of growth rates on factor income taxes. In particular, if human capital is produced with both human and physical capital (with CRS in the two inputs), the steady state growth rate of the economy depends on both factor tax rates. Therefore, in this case a zero long-run taxation of both labor and capital income will be optimal. However, if human capital accumulation uses human capital onty (with CRS), the sieady state growth rate of the economy will not depend on either factor income tax rate. When leisure takes

\footnotetext{
6 There are, of course, a number of other interesting issues regarding the optimal long run caxation of capital that we do not address bere. First, if government expenditure is endogenous and produclive - for example. when it enters in the production function for final or capital goods - the loog run oplimal tax on capital might not be zero (see Barro (1990), Jones, Manuelli and Rossi (1993a, 1993b), Judd (1990), Zhu (1992) and Corsetti (1992)). Second, if there are externalities in the production of final goods, as in Romer (1987) or in the production of human capital, as in Lucas (1988), the optimal tax plan might require subsidies to the aclivities with positive externalities (see Yuen (1991)). Third, there are interesting optimal taxation issues in stochastic settings (see Judd (1990), King (1990), Chari, Christiano and Keboe (1991a), Zhu (1992) and Corseti (1992)). Fourh, in the presence of reats generated by factors in fixed supply (such as labor in models without leisure) it may be optimal to tax capital in the long run if there are limits on the taxation of rents (Jones, Manuelli and Rossi 1993b). Fifth, there are papers shidying indirect taxation, in addition to factor income taxation (see Bull (1993a), Jones, Manuelli end Rossi (1993n, b) and Milesi-Ferrelti and Roubini (1994b)). Finally, there are inleresting issues of optimal taxation in open oconomy endogenous growth models; we address these issues in a ccmpanion paper (Milesi Ferretti and Roubini (1994a)); see also, Rebelo (1992), Buiter and Kletzer (1991), Correia (1992), Razin and Yuen (1992).
} 
the form of "home production" or quality time both factor income taxes will reduce the ratio between the steady state consumption of market goods and the consumption of the leisure activity.

(4) When human capital is produced only with human capital, the optimal long run taxation of labor and capital will depend on the model of leisure considered. If leisure is modeled as "quality time" or "home production", the growth rate of the economy does not depend on factor taxes but the steady state physical to human capital ratio depends on both tax rates. Since tax rates on both factors create an intertemporal distortion, the optimal long run tax on both human and physical capital will be zero in these cases. In the model without leisure, the tax on physical capital affects the steady state physical to human capital ratio but the tax on human capital does not; in the long run the tax on labor does not create any intertemporal or intratemporal distortion. In this sense, in the long-run the tax on labor is lump-sum: it is therefore optimal to tax labor but not physical capital in the long run.

(5) If the government is constrained in its borrowing ability by a balanced budget constraint capital and labor income should be taxed at the same positive rate in the long nin whenever it is optimal to have zero long run taxation of labor and capital income with an unconstrained government."

in summary, our results imply that the optimal long-run tax on both capital and labor income is zero (or symmetric if government borrowing is not allowed) under gencral conditions regarding the production of human capital and the specification of the leisure activity. In our setting, the only case in which the long run tax on capital is zero while the one on labor is positive is that of a model without leisure and with human capital produced with human capital only.

The rest of the paper is organized as follows. In Section 2 a'e present our general setup, and in Section 3 we solve for the competitive market equilibrium. In Section 4 we discuss the conditions under which the balanced growth rate of the economy and long-run factor allocations depend on the tax rates on capital and labor income. Section 5 presents the solution to the government's eptimal taxation problem, and Section 6 concludes.

\section{THE MODEL}

We consider a three-sector economy. The first sector produces final goods (and physical capital); the second produces human capital and the third produces a non-market good -. "hone production" or

\footnotetext{
${ }^{7}$ See Roubini and Sala-i-Martin (1992a, 1992b) for optimal taxation analyses ir which the governinent behavior is restricted 10 a balaneed budget in every period.
} 
"quality time". ${ }^{8}$

\subsection{Technology}

Physical output is produced with a constant returns to scale (CRS) technology that uses human capitid $/ f$ and physical capital $K$ as inputs. The tcchnology is assumed to take the Cobb-Douglas form:

$$
Y_{t}=A\left(\nu_{t} K_{t}\right)^{\alpha}\left(u_{t} H_{t}\right)^{1-\alpha}
$$

where $v(u)$ is the fraction of physical (human) capital devoted to the production of goods. The capital stock is assumed to depreciate at the rate $\delta$.

Human capital is also produced with a CRS technology that uses both luman and physical capital as inputs, as in Rebelo (1991). It depreciates at a rate $\delta$, equal for simplicity to the rate of depreciation of physical capital. ${ }^{9}$ The production function is assumed to be Cobb-Douglas as well: ${ }^{10}$

$$
H_{t}=B\left(x_{t} K_{t}\right)^{\beta}\left(z_{t} H_{t}\right)^{1-B}-\delta H_{t}
$$

where $x(z)$ is the fraction of physical (human) capital devoted to the accumulation of human capital. In equations (1) and (2) we have implicitly assiumed that the "point-in-time technologies" are linear: if a fraction $v$ of the capitai stock is eniployed in the production of final goods, the "effective capital" is $v K$. This assumption is not necessary for our results: the crucial assumption is that there are CRS in physical and human capital, the reproducible factors. ${ }^{\prime \prime}$

\subsection{The governuent}

The government needs to finance an exogenously given path of public expenditure, using factor income taxation and bonds. Without loss of generality, we assume that government bonds are taxexempt. The instantaneous budget constraint faced by the government is given by:

\footnotetext{
B The specification of the first rwo scetors is similar to Rebelo (1991), Mulligan and Sala-i-Martin (1993) and Caballé and Santos (1993).

Thi assumption allows the derivation of a simple closet form solution for the growtb rate, hut does not affect the qualitative nature of the results.

10 Our results generalize to the case in which the technologies are CRS with positive cross-derivatives. See Rebelo (1991) and Jones, Manuelli and Rossi (1993b).

1 Muligan and Sala-i-Martin (1993) discuss more in detail the role of the point-in-tine technologics.
} 


$$
B_{t}=r_{1} B_{t}+G_{t}-T_{t}
$$

where $B_{t}$ are government bonds, $r_{t}$ is their rate of inierest and $T_{t}$ is total revenue out of taxation. The usual no Ponzi game condition applies. In every period, the resource constraint of the economy is given by:

$$
\dot{K}_{t}=Y_{1}-\delta K_{t}-C_{1}-G_{t}
$$

where $C$ is private consumption and $G$ is government expenditure.

\subsection{Privase agents}

The econumy is inhabited by identical atomistic agents. They choose consumption, investment and the allocation of their human and physical capital with the purpose of maxinizing an interemporal utility function:

$$
U=\int_{0}^{\infty} e^{-\infty t} u\left(C_{t}, l_{t}, L_{t}\right) d t
$$

where $\rho$ is the rate of time preference, $l$ is leisure time and $L$ is "leisure activity", that could include for example home production. This maximization is subject to the constraint on human capial accumulation given by (2) and to the consumer's budget constraint:

$$
R_{1}^{K}\left(1-r_{t}^{R}\right) v_{t} K_{t}+R_{t}^{H}\left(1-\tau_{1}^{H}\right) u_{t} H_{t}+r_{t} B_{t}-C_{1}-B_{1}-K_{1}-\delta K_{t} \geq 0
$$

where $k^{K}, R^{f l}, r^{K}$ and $r^{H}$ are the rates of return and the tax rales on capital and labor income, respectively. Clearly total tax revenues $T$ are equal to $r^{R} R^{K} v K+T^{H} R^{H} u H$.

The leisure activity ("home production") uses human and phy'sical capital as inputs, with a CobbDouglas technology:

$$
L_{t}=\left[\left(1-v_{t}-x_{t}\right) K_{t}\right]^{\gamma}\left(w_{t} H_{t}\right)^{1-\gamma}
$$

where $w$ is the fraction of time devoted to "home production". Each individual's time endowment is normalized to one:

$$
l_{t}+u_{1}+w_{1}+z_{1}=1
$$

We assume that the instantaneous utility function takes a Constant Intenemporal Elasticity of 
Subs titution (CIES) form:

$$
\begin{array}{ll}
u\left(C_{t}, l_{i}, L_{t}\right)=\frac{\left(C_{t} l_{t}^{*} L_{t}^{\eta}\right)^{1-\theta}}{1-\theta}-1 & \theta \neq 1 \\
u\left(C_{t}, l_{t}, L_{t}\right)=\log C_{t}+\epsilon \log l_{t}+\eta \log L_{t} & \theta=1
\end{array}
$$

where $\theta$ is the inverse of the intertemporal elasticity of substitution. ${ }^{12}$ The utility function is similar to the rne in Benhabib, Rogerson and Wright (1991), and its functional form has been shown to be consistent with the existence of a balanced growth path by King, Plosser and Rebelo (1988). Various subo ses can be identified. When $\eta=0$, we have a standard formulation of the utility function in which leisure is "raw time", as in most endogenous growth models with leisure (Lucas 1990, Jones, Manuelli and Rossi 1993a, 1993b, Bull 1993a). Since this is the most widely srudied case, we will star first with specifications of the leisure activity where capital inputs (both human and physical) enter in the production of leisure in addition to raw time. In particular, when $\epsilon=0$ and $\eta>0$, leisure is equivalent to a form of "home production", as in Greenwood and Hercowitz (1991). A special case of this occurs when $\gamma=0$, so that leisure is "quality time", as in Becker (1965), Heckman (1976) and Retelo (1991).

\subsection{Firms}

Firms rent capital from households at the rate of interest $R^{K}$ and hire labor at the wage rate $R^{4}$. They will hire labor and capital up to the point at which their marginal product equates their marginal cost:

$$
R_{t}^{K}=\alpha A\left(\frac{v_{t} K_{t}}{u_{t} H_{t}}\right)^{\alpha-1}
$$

12 The qualilative nature of our results would be unchanged if we adopted the more general specification:

$$
U(C, L, l)=(1-\theta)^{-1}\left[\left[\frac{C^{*}+\eta L^{*}}{1+\eta}\right)^{\frac{1+\eta}{\pi}} l^{\cdot}\right]^{1-\theta}-1
$$

which reduces to (9) for $\pi=0$. 


$$
R_{i}^{H}=(1-\alpha) A\left(\frac{v_{t} K_{t}}{u_{t} H_{t}}\right)^{\alpha}
$$

\section{THE COMPETITIVE EQUILIBRIUM}

The representative consumer takes the paths of $\tau^{\mathbb{R}}$ and $r^{\mathrm{H}}$ as given and chooses the paths of $C$, $B, K, H, l, u, v, x, w, z$ to maximize (5) subject to (2) and (6). We will now focus on the case in which leisure is "home production". Analytically, this implies $\epsilon=0$, so that $l=0$ and $w=J \cdot u-z$ (by equation 8). Subcases are the "quality time" model $(\gamma=0)$ and the "ro leisure" model $(\eta=0)$. W'e will consider the "raw time" model of leisure $(\epsilon>0, \eta=0)$ in Section IV.

Defining private non-human wealth $X_{t} \equiv K_{t}+B_{p}$, we can re-write (6) as follow's:

$$
r_{t} X_{t}-\left[r_{t}+\delta-R_{t}^{K}\left(1-\tau_{t}^{K}\right) v_{t}\right] K_{t}+R_{t}^{H}\left(1-\tau_{t}^{H}\right) u_{t} H_{t}-C_{t} \geq \dot{X}_{t}
$$

The first-order conditions with respect to $C, X, K, H, v, x, u$ and $z$ can be expressed as follows:

$$
\begin{gathered}
e^{-\rho t} C_{t}^{-\theta} L_{t}^{\eta(1-\theta)}=\lambda_{t} \\
-\frac{\dot{\lambda}_{t}}{\lambda_{t}}=R_{t}^{K}\left(1-\tau_{t}^{K}\right)-\delta=r_{t} \\
-\frac{\mu_{t}}{\mu_{t}}=(1-\beta) B\left[\frac{x_{t} K_{t}}{z_{t} H_{t}}\right]^{\beta}-\delta \\
R_{t}^{K}\left(1-\tau_{t}^{K}\right) K_{t}=\frac{\gamma \eta}{1-\nu_{t}-x_{t}} C_{t} \\
\frac{\gamma \eta}{1-v_{t}-x_{t} e^{-\rho t} C_{t}^{1-\theta} L_{t}^{\eta(1-\theta)}=\mu_{t} B \beta K_{t}}\left[\frac{x_{t} K_{t}}{z_{t} H_{t}}\right]^{\beta-1} \\
R_{t}^{H}\left(1-\tau_{t}^{H}\right) H_{t}=\frac{(1-\gamma) \eta}{1-\mu_{t}-z_{t}} C_{t}
\end{gathered}
$$




$$
\frac{(1-\gamma) \eta}{1-u_{t}-z_{t}} e^{-o t} C_{t}^{1-\theta} L_{t}^{\eta(I-\theta)}=\mu_{t} B(1-\beta) H_{t}\left(\frac{x_{t} K_{t}}{z_{t} H_{t}}\right)^{\theta}
$$

The remaining two FOCs are the constraints (2) and (6). Equation (13) states that the shadow price of consumption (physical capital) must equal the marginal utility of consumption in evcry period. Equation (14) is the FOC for capital accumulation: the rate of change of the shadow price of consumption must equal the marginal product of capital net of tax, which must also equal the rate of return on government bonds. Equation (15) is the corresponding FOC for human capital accumulation, relating the change in the shadow price of human capital to its marginal rate of return. Equation (16) and (18) describe the optimal allocation of physical and human capital respectively between production of market goods and "home production". Finally, conditions (17) and (19) describe the optimal allocation of physical and human capital between the "education" sector and home production.

The transversality conditions are:

$$
\begin{aligned}
& \lim _{r-\infty} \lambda_{t} K_{t}=0 \\
& \lim _{\rightarrow-\infty} \mu_{1} H_{t}=0
\end{aligned}
$$

Using equations (10), (11) and (16)-(19) we can express the sectoral allocation of factors as a function of technology parameters and taxes:

$$
\frac{v_{t}}{u_{t}}=\frac{\alpha}{1-\alpha} \frac{1-\beta}{\beta} \frac{1-\tau_{t}^{K}}{1-\tau_{t}^{H}} \frac{x_{t}}{z_{t}}=\frac{\alpha}{1-\alpha} \frac{1-\gamma}{\gamma} \frac{1-\tau_{t}^{K}}{1-\tau_{t}^{H}} \frac{1-v_{t}-x_{t}}{1-u_{t}-z_{t}}
$$

According to (21), when the tax on !abor incone (capital income) rises (falls), the capital/labor ratio in the sector producing goods rises with respect to the capital/labor ratio in the sector producing human capital and with respect to the capital/labor ratio in the home production sector. It is interesting to note that changes in tax rates do not cause changes in the relative capital intensity between the education sector and the home production sector, since both these sectors are not directly taxed.

This economy will exhibit a balanced growth path, along which consumption, physical capital and human capital grow at the same rate, while factor allocations $(u, v, x$ and $z)$ remain constant, ${ }^{13}$ Logdifferentiating (13) and using the fact that factor allocations are constant along the balanced growth path,

\footnotetext{
${ }^{13}$ Mulligan and Sala-i-Martin (1993), Caballe and Santos (1993) and Barro and Sala-i-Martin (1994) give the necessary condilions for the existence of a balanced growth path.
} 
we obtain

$$
\frac{C}{C}=-\frac{1}{\theta-\eta(1-\theta)}\left(\rho+\frac{\dot{\lambda}}{\lambda}\right)
$$

where time subscripts for variables along the balanced growth path have been omitted. Along such path, the shadow prices of physical and human capital must decline at the same rate. Equating (14) and (15) we can determine the physical to human capital ratios in the production, human capital and "home" sectors along the balanced growth path:

$$
\begin{aligned}
\frac{\nu K}{u H} & =\left[D_{0}\left(1-\tau^{K}\right)^{1 \cdot \beta}\left(1-\tau^{H}\right)^{-\beta}\right]^{\frac{1}{1-\alpha+\beta}} \\
\frac{x K}{2 H} & =\left[D_{1}\left(1-\tau^{K}\right)^{\alpha}\left(1-\tau^{H}\right)^{1-\alpha}\right]^{\frac{1}{1-\alpha+\beta}} \\
\frac{(1-\nu-x) K}{(1-u-z) H} & =\left[D_{2}\left(1-\tau^{R}\right)^{\alpha}\left(1-\tau^{H}\right)^{1-\alpha}\right]^{\frac{1}{1-\alpha+\beta}}
\end{aligned}
$$

where the terms $D$, are constants involving the technology parameters $\alpha, \beta, A$ and $B$, reported in the Appendix. 14 The ratio of "market" consumption to leisure can be determined in an analogous fashion, and is given by:

$$
\frac{C}{L}=\left[D_{3}\left(1-\tau^{H}\right)^{(1-\gamma+\theta)(1-\alpha)}\left(1-\tau^{K}\right)^{1-\alpha \gamma+\beta}\right]^{\frac{1}{T-\alpha+\beta}}
$$

Clearly, higher factor income tax rates will tend to shift consumption from "market" goods to "home production".

Plugging (14) into (22) and using (10) and (23) we obtain the balanced growth rate of the economy:

$$
\frac{C}{C}=\frac{1}{\theta-\eta(1-\theta)}\left[\left[D_{4}\left(1-\tau^{R}\right)^{\alpha \beta}\left(1-\tau^{H}\right)^{\beta_{(1-\alpha)}}\right]^{T-\alpha \cdot E}-\delta-\rho\right]
$$

The steady state net real interest rate can be determined using (10), (14) and (23):

\footnotetext{
if If the depreciation rales of human and physical capital were different, it would nol be possible 10 express these ratios in closed form.
} 


$$
r=\left[D_{4}\left(1-T^{K}\right)^{\alpha \beta}\left(1-\tau^{H}\right)^{B(1-\alpha)}\right]^{\frac{1}{T-\alpha-\beta}}-\delta
$$

Ecilations (23)-(26) show that both tax rates will in general distort the allocation of factors between se:tors and reduce the rate of growth of the economy.

\section{TAXATION AND LONG-RUN GROWTH}

We will now-discuss the main results of the balanced growth solution of our model. In particular, we analyze the conditions under which the balanced growth solutions of the model depend on the tax rates on labor $\left(T^{H}\right)$ and capital income $\left(T^{K}\right)$.

Proposition 1 When physical capial does not enter in the production of human capital $(\beta=0)$, the stendy stase growth rate of the economy is independent of the tax rates on capital and labor income regardless of how the leisure activity is modeled. In this case:

$$
\frac{C}{C}=\frac{1}{\theta-\eta(1-\theta)}[B-\delta-\rho]
$$

Proof Sec equation 25.

The intuition for this result is simple. If human capital is produced with human capital only, an increase in the labor tax rate will reduce the return to current work effort but it will also reduce the return to human capital accumulation (and the return to the leisurc activity) by the same amount. Therefore, the fraction of time spent studying -- which in this case determines the growth rate -- is urichanged.

The growth rate defined by equation (27) is equal (up to a constant of proportionality) to the balanced growth rate of economies a la Lucas (1988) where human capital accumulation is CRS in huinan capital only and there is no leisure $(\eta=0)$ (see Barro and Sala-i-Martin, 1934). Our analycis generalizes that result by showing that, in the Lucas case of $\beta=0$, a qualitatively similar steady state solution is obtained when we consider economies where leisure is introduced and modcled as "quality time" or "home production". Specifically, the growth rate will be independent of the technological parameters for the production of final goods and physical capital ( $\alpha$ and $A$ ) while the real interest rate will be independent of preferences and related to the productivity level of human capital in the education sector, given by $B$. 
Proposition 2 The growth rase of the econony is independent of the copiral intensity of the production of leisure $(\gamma)$. That is, the "quality time" and "home production" models of leisure are equivalent with respect to the steady state growth rate of the economi.

Proof See equation (25).

This proposition suggests that, as long as leisure is produced with constant returns to reproducible factors, as is the case in the "quality tine" and "home production" models, what matters for growth is only the relative preference of agents for leisure relative to consumption (given by the parameter $\eta$ ) and not the specific form in which the leisure good is produced. In particular, the capital intensity of the leisure activity $(\gamma)$ has no effects on the growth rate of the economy.

Proposition 3 The real interest rate in the "quality time" and "home production" models of leisure is the same as in a model with no leisure $(\eta=0)$, while the growth rates are proportional, with a proporrionality ratio $([\theta /(\theta-\eta(1-\theta))])$ that depends only on parameters of the urility function $(\theta$ and $\eta)$.

Proof See equations (25) and (26). \|

A similar result was derived by Rebelo (1991) who compared the growth rates in a model with leisure as "quality time" and in a model where an exogenous flaction of time is devoted to leisure. ${ }^{\text {is }}$ This equivalence of "quality time" and "home production" models of leisure with the case of no leisure results from the fact that leisure is modeled as a non-market activity producod with constant returns to scale to reproducible factors. In these two case, leisure can therefore be reinterpreted as a non-market consutnption good and the model is substantially equivalent to one in which there is no leisure.

Proposition 4 when the leisure activit exhibits CRS in reproducible factors, the ratio between consumption and leisure along the balanced growth path is a negative function of both tax rates. regardless of $\beta$.

\footnotetext{
15 Benhabib, Rogerson and Wright (1991) show that a model with home production is observationally equivaleat to a model without home production, but with different preferences.
} 
Proul See equation (24). \|

The intuition is very simple: when factor income taxes are positive, individuals will shift cons: Imption to a non-taxed activity such as leisure.

Proposition 5 When $\beta=0$, in the model with no leisure the steacty state physical to human capital ratio in the economy is independent of the tax rate on labor income but a negative function of the tax rate on capiul income; in the models where leisure is "quality time" or "home producrion" this ratio depends on both factor income tax rates.

Proof From (23), the equilibrium capital/labor ratio in the economy is given by

$$
\frac{K}{H}=\frac{u}{v}\left[\alpha \frac{A}{B}\left(1-\tau^{\Gamma}\right)\right]^{\frac{1}{1-\alpha}}
$$

From Proposition 1, we know that when $\beta=0$, the fraction $z$ of time spent accumulaing human capital is independent of both tax rates. When $\gamma>0$, we can the equality between the first and the third term in (21) to express $v$ as a function of $u$ and both tax rates. Using the economy's resource constraint (4), we can establish that $u, v$ and $v / u$ are a function of both tax rates. Since from (23) we know that $v K / u H$ depends only on $r^{\mathrm{x}}$, it follows that $K / H$ is a function of both tax rates. When $\gamma=0, v=1$; the resource constraint (4) establishes that $u$ is a function of both tax rates. From equation (28) it follows that $K / H$ is also a function of both tax rates. Finally, when there is no leisure $z=1 \cdot u$; since $z$ is independent of both tax rates (Proposition 1), so is $u$. In this case (28) establishes that $K / H$ depends only on the tax rate on physical capital. \#

Intuitively, when leisure is modeled as "quality time" or "home production" the tax on labor income does not affect the fraction of time spent studying ( $z$ ), and therefore does not affect the growth rate. However, it affects the allocation of time between work and leisure activities; in particular, an increase in the labor tax reduces the fraction of time spent working and increases time spent in the leisure activity. Therefore, the equilibrium human and physical capital in the economy will be affected by the labor tax.

Proposition 5 is important for the derivation of the optimal taxation of factors. In fact, when $\beta=0$ and there is no leisure, the labor tax does not create any intertemporal distortion: it does not affect 
either the growth rate of the cconomy or the capital labor ratio in the economy. Conversely, if leisure is modeled as "quality time" or "home production", the labor tax does not affect growth but it creates an intertemporal distortion since the ecoromy-wide $K / H$ is affected. A tax on capital income is always distortionary when $\beta=0$ because it affects the physical to luman capital ratio regardless of whether there is leisure or not in the model.

Proposition 6 When physical capital enters in the production of human capital $(\beta>0)$, tax rates on capital and labor income reduce the long-nun growth rate of the economy. The stecty state physical to human capital ratios in the final goods and human capital sectors will also depend on both factor tax rates.

Proof see equation (25). \|

The intuition for the proposition is easier to present for the case of no leisure fout is the same in the equivalent cases of leisure as "quality time" or "home production"). W'e showed above that when $\beta=0$, the return to and the cost of human capital accumulation (i.e. the net of tax wage) are affected in the same proportion by a change in labor taxes, leaving the time allocation decision unchanged. In other terms, since the cost of human capital accumulation is effectively tax-deductible, labor income taxation does not affect the incentive to accumulate human capital. ${ }^{16}$ However, if physical capital is also used in the production of new human capital $(\beta>0)$, the return to human capital is reduced more than its cost. In particular, the cost of physical capital inputs used in the production of human capital is not reduced by the labor income tax since these inputs are not tax deductible. Morc generally, as suggested by Trostel (1993), if any other inputs in addition to human capital cnter in the production of human capital, its return will be reduced by more than its cost. Thereinre human capital accumulation will be reduced by an increase in the labor tax rate. ${ }^{17}$

The above results imply that, for the three specifications of the leisure activity considered so far (the "quality time", the "home production" and the "no leisure" models), the specification of the human capital accumulation furction has important implications for the dependence of growth rates on factor income taxes. In particular, if human capital is produced with both human and physical capital (with

\footnotetext{
${ }^{10}$ See Trostel (1993) for a detailed presen iation of this argument.

17 See also Bull (1993a) and Jones, Manuelli and Rossi (1993b).
} 
CRr in the two inputs), the steady state growth rate of the aconomy depends on both factor tax rates. Hos ever, if human capital accurulation uses human capital enly (with CRS), the steady state growth rate of the economy will not depend on either factor income tax rate. When leisure is a good produced with CRs in reproducible factors, both factor income tax rates will shift consumption away from "market goods" and towards leisure.

What happens in the case in which leisure is not produced with constant returns to reproducible factcrs? Ore such case - leisure modeled as a "raw time" activity -- is the one most studied in the literature, ${ }^{18}$ In this case "raw time" is a non-reproducible factor that is constrained by the agent's total time endowment. As already well known (see King, Plosser and Rebelo (1988)), such a specification of leisure is consistent with a balanced growth path only under particular functional forms for the agent's utility. Even in these cases, it is not possible to derive analytically a closed form solution for the balarced growth rate of the economy since the first order conditions of the competitive equilibrium are non inear. However, the evaluation of these first order conditions allows us to infer whether the growth rate of the economy depends on the factor tax rates or not:

Proposition 7 If leisure is modeled as "raw time" .. or, more generally, as an activity not produced with CRS in reproducible factors -- the balanced growth rate of the economy will al ways depend on the tax rates on capital and labor income regardless of whether physical capiral inputs enter or nor in the production of human capital.

Proof The solution to the consumer maximization problen yields the following (semi-reduced) expression for the growth rate:

$$
\frac{C}{C}=\frac{1}{\theta}\left(\left[D_{4}\left(1-\tau^{K}\right)^{\alpha \beta}\left(1-\tau^{H}\right)^{\beta(1-\alpha)}(u+z)\right]^{\frac{1}{1-\alpha+\beta}}-\rho-\delta\right)
$$

where $\mathrm{D}_{4}$ is the same constant as in equation (25). The Appendix shows that the growth rate will depend on both tax rates even when $\beta=0$, since $u$ and $z$ depend on the tax rates irrespectively of $\beta$.

The expression (29) is very similar to (25) - the growth rate for the case in which leisure is

18 See Chamley (1986), Lucas (1990), Jones, Manuelli and Rossi (1993a, 1993b) and Bull (1993a) for such a specification of lejsure in optimal taxation analyses. In our general framework, the case of leisure as "raw time" corresponds to $\epsilon>0$ and $\eta=0$ in equation (9). 
"home production". The crucial difference is the term $u+z$, the share of tinie spent working and accumulating human capital.

The intuition for the result can be more easily obtained by considering the case where $\beta=0$, in which case the growth rate can be expressed as $B z-\delta .{ }^{19}$ We showed above that when there is no leisure in the model or when leisure is produced with constant returns to reproducihle factors the steady state real interest rate depends only on the technology of human capital $(B)$. In those cases, an increase in the stock of human capital increases the productivity of all the time endowment, including the time spent in leisure activities. Moreover, in this case the return to and the cost of human capital accumulation (i.e. the net of tax wage) are affected in the same proportion by a change in labor taxes so that the time spent accumulating human capital does not change.

When leisure is modeled as "raw time" instead, an increase in human capital will raise the productivity of time spent producing goods or accumulating human capital but will not affect the marginal utility of leisure. Therefore, the return to the accumulation of human capital will now depend on the time spent in leisure activities. Since the time spent in leisure is a function of the relative preferences over consumption and leisure, the equilibrium real interest rate will now also depend on preferences and not only on technology.

Consider now the effects of an increase in the labor tax: while the relative cost of and return to working versus accumulating human capital are unchanged, the return to the leisure activity is increased since the time spent in leisure is untaxed. The ensuing increase in time spent in leisure reduces the time spent accumulating human capital and therefore its return. The reduction in the return to investment in human capital will then imply that the equilibrium real interest rate is reduced and therefore the raie of growth of the economy is reduced in the steady state. A similar argument can be made for the effects of changes in capital income taxes on growth. It then follows that, even if $\beta=0$, in the model with leisure as "raw time" the growth rate of the economy will depend on the tax rates on both factors of production. A similar argument can be used to show that the growth rate depends on the two tax rates when $\beta$ is positive.

The result that in the "raw time" leisure model the growth rate is a function of both tax rates independently of whether $\beta$ is zero or not is in contrast to the results obtained in the models without leisure or with leisure produced with CRS in reproducible factors. In those models, the growth rate of the economy is dependent on both tax rates when $\beta>0$ but independent of them when $\beta=0$.

19 See Rebelo (1991) for an explanation along the same lines. 


\section{OPTIMAL TAXATION ANALYSIS}

So far, we have discussed the conditions under which the growth rate of the economy and the capital ratios in the various sectors depend on the tax rates on labor and capital income. We have not yet determined the conditions under which it will be optimal to have a zero long-run taxation of a factor of production. A formal analysis of optimal tax rates on the two factors requires the solution of a "Ramsey planner's problem" (Ramsey, 1927) where the government chooses the path of tax rates with the purpose of maximizing the representative agent's welfare, taking into account the cptimizing bahavior of this agent. We now turn to this probiem.

\subsection{The Ramsey planner's problem}

The government has to take into account the opimizing behavior of private agents when deciding the optimal structure of taxation. One way to solve the optimal taxation problem is the following: the government chooses taxes so as to maximize the consuner's indirect utifity function, subject to the firstorder conditions of the constimer's maximization problem, as in Chamley (1986). A different and simpier approach, based on Lucas and Stokey (1983) is a'so possibie. This approach consists in fornulating the government's problem as a restricted Ramsey planner problem, in which the government chooses quantities directly, subject to the consumer's intertemporal budget constraint and to the constraints related to the consumer's optimal allocation of human and physical capital. These constraints are derived from the consumer's first-order conditions; the later, togcther with the firm's FOCs, are used to eliminate factor returns and taxes from the constraints so as to express the problem in terms of quantities only. The optimal quantities chosen by the government will then implicitly determine tax rates and factor rcturns. This is the approach followed by Lucas (1990); Yuen (1990); Chari, Christiano and Kehoe (1991a,b); Bull (1993a, b), Jones, Manuelli and Rossi (1993a, b) among others.

The optinal taxation analysis, formally developed in the Appendix, yields the following three results: ${ }^{20}$

Proposition 8 When $\beta>0$, the optinul tax rate on borh human and physical capiral is zero in the long run both when leisure is CRS in reproducible factors $(\epsilon=0, \eta>0)$ ard when leisure does nor yield utility $(\eta=\epsilon=0)$.

20 As other optimal taxation studies, our analysis does not prove formally existence and uniqueness of the optimal taxation plan. 
Proof See the Appendix. $\|$

Heuristically, the proof consists in guessing that both taxes are equal to zero along a balanced growth path, and then verify that this is a solution so the system of equations given by the first-order conditions and the constraints. ${ }^{21}$

The intuition for the proposition when $\beta>0$ can be easily understood by considering the relation between the growth rate of the economy and the tax rates. The analysis of Chamley suggests that any tax that distorts a long run intertemporal decision should be set equal to zero. In an endogenous growth framework, any tax distortion that reduces the long-run growth rate of the economy will have large and permanent costs (in terms of present discounted value of lost consumption and utility) and should therefore be set equal to zero. Since the balanced growth rate of the economy is dependent on both tax rates in models without leisure and in models where leisure is CRS in reproducible factors when $\beta>0$, it follows that the optimal tax on labor and capital income should be zero in these cases.

The basic principle that any tax. the affects long run growth should be set to zero in the long run leads to the next proposition regarding optimal taxation in the specifications of leisure as "raw time".

Proposition 9 In the "raw time" model of leisure, the oprimal long-run tax rate on capital and labor income is zero regardless of whether capital inputs enter or not in the production of human capital ile, regardless of the value of $\beta$ ).

Proof See the Appendix. \|

An immediate implication of this Proposition is that the optimal tax on labor income in the Lucas (1990) model is zero when the accumulation of human capital is endogenous.

While a dependence of the long-run growth rate on a tax rate implies that such a tax rate should be set equal to zero in the long run, what can we say about the cases in which long run groxth is independent of tax rates? Such independence is obtained, in our model, in three models of leisure (w'hen leisure is CRS in reproducible factors and when there is no leisure) whenever $\beta=0$.

There is an important difference between models where leisure is produced with CRS in

21 See Bull (1993a) and Jones, Manuelli and Rossi (1993b) for a similat methodology. 
reproducible factors and models in which there is no leisure, as the following proposition shows:

Proposition 10 When $\beta=0$, the optimal long run tax rate on capital incomie will be equal to zero; when the leisure activiry is "quality time" or "home production" the oprimal long run rax rate on labor income will be zero, while it will be positive when leisure does not bring utility.

\section{Proof See the Appendix. $\|$}

The intuition for this result goes as follows. When leisure is produced with CRS in reproducible factors, the taxes on labor and capital income distort the economy's long-run aggregate capital/labor ratio, as proven in Proposition 5. Therefore labor and capital income should be untaxed in the long run. When there is no leisure in the model, however, a tax on labor income does not distort the capital/abor ratio and resource allocation choices, because it reduces the opportunity cost of human capital accumulation in the same proportion as the returns to education, and therefore leaves the allocation of labor between production and education unchanged. Indeed, in the long run the labor tax is non distorionary, and should therefore be set at a positive level. The optimal long-run tax on capital income is instead zero, because it distorts the economy's long-run capital/labor ratio.

We do not study the complicated issue of optimal taxation along the transition to the balanced growth path. Clearly, when long-run taxes are zero, the government needs to accumulate budget surpluses in the short run in order to finance government expenditure with the accumulated assets in the long run. Unlike other models in which physical capital can be used only in production, we speculate that the taxation of human and physical capital along the transition path will be relatively similar. The reason is that taxing physical capital at rates close to $100 \%$ w'ill induce private agents to shift capital to the untaxed education and home production sectors. In other terms, while the supply of $K$ is relatively inelastic in the short run, $v_{t}$ responds to current tax rates.

\section{S.2 Growth-Maximizing Tax Policies with a Balanced Budget}

As we already mentioned, optimal taxation plans in dynamic growth models generally feature high factor income taxes in the short run (when factors are in semi-fixed supply) and lower (possibly zero) taxes in the long run. Given an exogenous path of government expenditures this optimal taxation plan consists of taxing both factors in the short run, and financing spending in the long run through accumulated budget surpluses. This implies that the government should be able to accumulate enough 
assets in the short run to be able live off their return in the long run. Such an accumulation of assets by the government is clearly not empirically realistic.

It is therefore interesting to consider the nature of an optimal taxation plan when the ability of the government to borrow or lend is restricted. We study which tax policies will be growth maximizing (i.e. welfare maximizing) in the long run in the limiting case where no intertemporal burron'ing is allowed so that the government has to balance its budget in every period. We consider only the steady state and assume that government spending is a constant fraction of output. If the government has to run a balanced budget in every period, its budget constraint becomes:

$$
g=\frac{G}{Y}=\alpha \tau^{R}+(1-\alpha) t^{H}
$$

where $g$ is the steady state ratio of government spending to output. We can then consider which steady state tax policies will maximize the growth rate by maximizing the growth solution (25) (for the general case of $\beta>0$ ) subject to the above government budget constraint (30). The solution of this problem is:

$$
r^{x}=r^{H}=8
$$

The equation shows that the growth-maximizing capital and labor income tax rates are equal, i.e. a common income tax on all factor incomes is optimal. The result is interesting because it suggests that, as long as the growth rate of the economy is affected by both tax rates, the optimal long run tax policy is to tax both factors similarly. As seen in section 5.1, if the behavior of the government is not constrained (so that it can borrow and lend), labor and capital should be taxed at the same long run rate of zero. Sinilarly, for the functional forms we use, if the government is constrained to run a budget balance in every period, the optimal long run tax on labor and capital will still be the same for both factors and equal to the government spending to output ratio that has to be financed in every period.

More generally, the finding of a long run dependence of the growth rate on both factors breaks the asymmetry between labor and capital that lead Chamley to the result that capital income should not be taxed and labor income should be taxed in the long run. If growth depends on both tax rates, the nature of optimal (growth-maximizing) policies is to tax the two factors in a symnetric fashion.

\section{CONCLUDING REMARKS}

In this paper we have considered the role of the human capital accumulation technology and the nature of the leisure activity in determining the optimal taxation of labor and capital. Traditional optimal 
taxation analyses in exogenous growth models stressed that the tax rate on capital income should be zero in the long run, while the one on labor should be positive. We have shown that in endogenous grow'th models this result is replicated only under restrictive specifications of human capital accumulation and leisure production. Under more general specifications of these processes, capital and labor income should be taxed similarly in the long run. In particular, our results imply that the optinal long-run tax on both capital and labor income is zero (or symmetric if borrowing is not allowed) under very general conditions regarding the production of human capital and the specification of the leisure activity. The only case in which the long run tax on capital is zero while the one on labor is positive is that of a model without leisure and with human capital produced with human capital only.

This optimal taxation analysis, like most its predecessors, ${ }^{22}$ ignores important time-consistency issues, since the government is assumed to choose irrevocably an optimal tax plan at period zcro. However, time consistency appears more tractable in this model, since physical capital has alternalive uses that are non taxable and therefore confiscatory tax rates are not feasible. A general but unrealistic feature of the optinal taxation solution is the accumulation of budget surpluses in the shor run to finance government expenditure without recourse to distortionary taxation in the long run. This resul: is due to the fact that reproducible factors are supplied relatively inelastically in the shor nin but elastically in the long run. Future research should re-examine the issue of dynamic optimal taxation subject to a realistic set of restrictions on government's behavior.

The analysis in this paper is framed in a closed economy context and does noi study indirect taxation. In Milesi-Ferretti and Roubini (1994a) we consider optimal taxation issues in a small open economy, while in Milesi-Ferretti and Roubini (1994b) we examine the impact of consumption taxes on growth and factor allocations, and its implications for optimal taxation.

\footnotetext{
22 An exception is Benhabib and Velasco (1994).
} 


\section{APPENDIX}

A1. Value of parameters in equations (23)-(25)

The terms $D_{i}$ (equations (23), (24) and (25)) are given by:

$$
\begin{aligned}
& D_{0}=\frac{\alpha A}{(1-\beta) B}\left(\frac{\alpha}{1-\alpha} \frac{1-\beta}{\beta}\right)^{\beta} \\
& D_{1}=\frac{\alpha A}{(1-\beta) B}\left\{\frac{1-\alpha}{\alpha} \frac{\beta}{1-\beta}\right)^{1-\alpha} \\
& D_{2}=\frac{\alpha A}{(1-\beta) B}\left(\frac{1-\alpha}{\alpha}\right)^{1-\alpha}\left(\frac{1-\beta}{\beta}\right)^{\beta}\left(\frac{\gamma}{1-\gamma}\right)^{1-\alpha+\beta} \\
& D_{3}=\left[\left(\frac{(1-\alpha) A}{(1-\gamma) \eta}\right)^{1-\alpha+\beta}\left(\frac{\alpha A}{(1-\beta) B}\right)^{\alpha-\gamma}\left(\frac{\alpha}{1-\alpha}\right)^{\gamma(1-\alpha)+\alpha \beta}\left(\frac{1-\beta}{\beta}\right)^{\beta}\left(\frac{\gamma}{1-\gamma}\right)^{\gamma(1-\alpha+\beta)}\right] \frac{1}{1-\alpha \cdot \beta} \\
& D_{4}=(\alpha A)^{\beta}[B(1-\beta)]^{1-\alpha} \\
& \left.\frac{1-\alpha}{\alpha} \frac{\beta}{1-\beta}\right)^{(1-\alpha)}
\end{aligned}
$$

A2. The "raw time" model of leisure

When leisure is expressed as "raw time", the consumer's problem takes the following form:

$$
\begin{gathered}
\operatorname{Max} U=\int_{0}^{\infty} \frac{\left(C_{t} l_{t}^{*}\right)^{1-\theta}}{1-\theta}-1 \\
\text { s.t. } \\
K_{t}+B_{t} \leq R_{t}^{\prime \prime}\left(1-\tau_{t}^{H}\right) u_{t} H_{t}+R_{t}^{K}\left(1-\tau_{t}^{K}\right) v_{t} K_{t}+r_{t} B_{t}-C_{t}-\delta K_{t} \\
H_{t} \leq B\left(x_{t} K_{t}\right)^{\beta}\left(z_{t} H_{t}\right)^{1-\beta}-\delta H_{t} \\
l_{t}+u_{t}+z_{t}=1
\end{gathered}
$$

Evaluation of the first-order conditions along the balanced growth path yields the following expression for economic growth:

$$
\frac{C}{C}=\frac{1}{\theta}\left(\left[D_{4}\left(1-\mu^{R}\right)^{\alpha \beta}\left(1-\mu^{\mu}\right)^{\theta(1-\alpha)}(u+z)\right]^{\frac{1}{1-\alpha+\beta}}-\rho-\delta\right)
$$

where $D_{4}$ is the same constant as in equation (25). This expression is very similar to the growth rate for the case in which leisure is "home production" (equation 25). The crucial difference is the term $u+z$, the share of time spent working and accumulating human capita. The values of factor allocations $u, v$ 
and $z$ are determined implicitly by the following three relations:

$$
\frac{\nu}{u}=\frac{\alpha}{1-\alpha} \frac{1-\beta}{\beta} \frac{1-\tau^{K}}{1-\tau^{H}} \frac{1-\nu}{z}
$$

that relates the capital/labor ratio in the two sectors;

$$
B z\left[\frac{D_{1}\left(1-\tau^{K}\right)^{\alpha}\left(1-\tau^{H}\right)^{1-\alpha}}{u+z}\right]^{\frac{\beta}{1-\alpha+\beta}}-\delta=\frac{1}{\theta}\left(\left[D_{4}\left(1-\tau^{K}\right)^{\alpha \beta}\left(1-\tau^{H}\right)^{(1-\alpha) \beta}(u+z)\right]^{\frac{1}{1-\alpha+\beta}}-\delta-\rho\right)
$$

which is obtained by equating the growth rate of buman capital and consumption along the balanced growth path and

$$
1-g=\frac{1-\alpha}{\eta} \frac{1-u-z}{u}\left(1-\tau^{H}\right)+\frac{\alpha}{1-\beta} \frac{z}{v(u+z)}\left(1-\tau^{R}\right)
$$

which is obtaincd from the resource constraint of the economy. $g$ is the ratio of public expenditure to output. The dependence of $u$ and $z$-- and therefore of the growth rate -- on both tax rates is clcar frum equations (A3)-(AS). When $\beta=0, v=1$ (all capital is used in production of goods) and from (A2) and (A4) it is straightforward to show that the growth rate is given by $\mathrm{Bz}-\delta$, where $z$ is determined implicilly by:

$$
\frac{\alpha B z}{B \theta z-\delta(\theta-1)+\rho}\left(1-\tau^{K}\right)+\frac{1-\alpha}{\eta} \frac{B(1-\theta z)+\delta(\theta-1)-\rho}{(\theta-1)(B z-\delta)+\rho}\left(1-\tau^{H}\right)=1-g
$$

and is clearly a function of both tax rates.

\section{A3. Optimal taxation when Ieisure is "home production"}

In this Appendix we prove formally the optimality of zero long-run taxcs on both human and physical capital for a model in which leisure takes the form of home production. The first step consists in expressing the consumer's intertemporal budget constraint (BBC) as a function of quantities only. By integrating forward the instantaneous consumer budget constraint (12) and imposing the transversality condition (20) and the no-Ponzi game condition, we obtain the following intertemporal budget constraint:

$$
\int_{0}^{\infty} e^{-\int r_{t}^{d z}}\left[C_{t}+\left(1-v_{t}\right) R_{t}^{K}\left(1-\tau_{t}^{R}\right) K_{t}-u_{t} R_{t}^{H}\left(1-\tau_{t}^{H}\right) H_{t}\right] d t=K_{0}
$$


where $r$ is defined as in (14) and initial debt $B_{0}$ has been assumed to be zero without loss of generality. Integrating the first-order condition (14) between zero and $t$ and using the F.O.C. for consumption (13) we get:

$$
\frac{\lambda_{t}}{\lambda_{0}}=e^{-\int_{0}^{1}\left[R_{0}^{\alpha}\left(1-r_{0}^{K}\right)-\delta\right] d z}=e^{-a t}\left(C_{r} / C_{0}\right)^{-\theta}\left(L_{t} / L_{0}\right)^{g(t-\theta)}
$$

The differential equations for human capital accumulation (2) and its shadow price (15) can be integrated forward to determine the value of the representative agent's human wealth. Using equations (16)-(19) human weal th can be expressed as follows:

$$
\mu_{0} H_{0}=\int_{0}^{\infty} \lambda_{s}\left[R_{s}^{H}\left(1-\tau_{s}^{H}\right) H_{s}\left(1-z_{s}\right)-R_{s}^{R}\left(1-\tau_{s}^{R}\right) K_{s} x_{s}\right] d s
$$

Adding ( $A 9$ ) and (A7) the consumer's IBC becomes:

$$
\int_{0}^{\infty} \lambda_{t}\left[C_{t}+\left(1-v_{t}-x_{t}\right) R_{t}^{K}\left(1-\tau_{t}^{K}\right) K_{t}+\left(1-u_{t}-z_{t}\right) R_{t}^{H}\left(1-\tau_{t}^{H}\right) H_{t}\right] d t=\lambda_{0} K_{0}+\mu_{0} H_{0}
$$

The terms in $K_{t}$ and $H_{t}$ inside the integral sign represent die "value" of home production, while the RHS is the consumer's initial human and non-human wealth. Taxes can be implicitly" expressed as a function of quantitics, using the consumer's first-order conditions (16) and (18), reported here for convenience:

$$
\begin{aligned}
& R_{t}^{K}\left(1-\tau_{t}^{\boldsymbol{K}}\right) K_{t}=\frac{\eta \gamma}{1-\nu_{t}-x_{t}} C_{t} \\
& R_{t}^{H}\left(1-\tau_{t}^{H}\right) H_{t}=\frac{\eta(1-\gamma)}{1-u_{t}-z_{t}} C_{t}
\end{aligned}
$$

where $R^{H}$ and $R^{K}$ are determined by the firms' first-order conditions (equations 10 and 11 ).

Substituting (A11) and (A12) into (A10) we obtain:

$$
\int_{0}^{\infty} \lambda_{t} c_{t}(1+\eta) d t=\lambda_{0} K_{0}+\mu_{0} H_{0}
$$

Equation (A15) simply states that the PDV of consumption - including market goods and "home production" - has to be equal to the consumer's total wealth. This is an "implementability constraint" that the government's optimal plan needs to satisfy. 
In these modeis it is well known that, although the toral supply of human capital is inelastic, its "taxable" supply is elastic - if labor taxes are very high in the initial period, agents will devote their time to human capital accumulation and home production. It should be noted that in our serup, unlike in other papers, such as Chamley (1986) and Lucas (1990), the government would nol be able to "confiscate* physical capital even if it could tax its return at more than $100 \%$. The reason is that physical capital has alternative uses -- it can be employed for home production and for the production of human capital.

Using (A8) to substitute for $\lambda_{1}$ and $\lambda_{0}$; and substituting for $\mu_{0}$ from the consumer's FOCs, we can re-write (A13) as follows:

$$
\int_{0}^{\infty} e^{-\rho t}\left(C_{t} L_{t}^{\eta}\right)^{t-\theta} d t=\hat{W}_{0}
$$

where $\hat{W}_{0}$ depends only on time zero variables, and is given by:

$$
\hat{W}_{0}=\frac{1}{1+\eta} C_{0}^{-\sigma} L_{0}^{\eta(1-a)}\left[K_{0}+\frac{1-\alpha}{1-\beta} \frac{A}{B} H_{0}\left(\frac{v_{0} K_{0}}{u_{0} H_{0}}\right]^{\alpha}\left[\frac{x_{0} K_{0}}{z_{0} I_{0}}\right]^{-\varepsilon}\right]
$$

We now turn to the determination of the additional constraints that the consumer's behavior imposes on the government. The remaining FOCs of the consumer's optimal plan are equation (2) and equations (13)-(19). Of those, equation (13) determines $\lambda$; equation (18) defines implicity the tax rate on human capital equations (14) and (16) determine inplicitly the tax rate on physical capital and a constraint associated with physical capital accumulation:

$$
\int_{0}^{1} \frac{C_{s}}{\left(1-v_{s}-x_{s}\right) K_{s}} d s=\frac{1}{\gamma \eta}\left[\theta \log C_{t}-\eta(1-\theta) \log L_{t}-\theta \log C_{0}+\eta(1-\theta) \log L_{0}+(\delta+\rho) r\right]
$$

which is obtained substituting (A11) into (A8) and taking logs. Equation (17) and (19) deternine $\mu$ and a constraint that relates the capital intensities of home production and education:

$$
\frac{1-\nu_{t}-x_{t}}{x_{t}}=\frac{1-\beta}{\beta} \frac{\gamma}{1-\gamma} \frac{1-u_{t}-z_{t}}{z_{t}}
$$

and equation (15) and (2) determine a constraint associated with human capital accumulation:

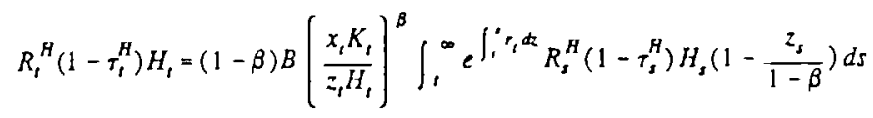


The LHS of this expression is the gain for the consumer if she increases narginally her labor supply $u_{t}$. This must be equal to the resources the consumer would have had by devoting one more unit to the accumulation of human capital (RHS). Note that these resources include not only the additional income from the time spent producing market goods $\left(u_{t}\right)$, but also from the time spent in "home production", because a higher human capital stock increases home production. Using (A7) and $(\mathrm{A} 12)$ the constraint (A18) can be written as:

$$
\left(C_{t} L_{t}^{\nabla}\right)^{1-\theta}=\left(1-u_{t}-z_{1}\right) B\left(\frac{x_{t} K_{t}}{z_{t} H_{t}}\right]^{\varepsilon} \int_{1}^{\infty} e^{-\rho(s-t)}\left(C_{s} L_{s}^{7}\right)^{1-\theta} \frac{1-\beta-z_{s}}{1-u_{s}-z_{s}} d t
$$

The government's restricted Ramsey plan consists in maximizing consumer's utility subject to the economy's resource constraint (4); the human capital "production" technology (2); the implementability constraint (A14); and the other constraints imposed by the consumer's behavior -. (A16), (A17) and (A19). Let $\downarrow$ be the Lagrange multiplier associated with the implementability constraint, and define $W_{1}=(1+\Psi)(1+\theta)^{-1}\left(C_{i} L_{i}^{7}\right)^{1-\theta}$. It is easy to see that the planner's problen can be re-formulated as follows:

$$
\operatorname{Max} \int_{0}^{\infty} e^{-\infty} W_{1} d t-\psi \hat{W}_{0}
$$

subject to the constraints (4), (2), (A16), (A17) and (A19) which we associate the multipliers $\lambda_{t}, \mu_{t}, \phi_{r}$ $\xi_{t}$ and $v_{t}$ respectively. Let $\sigma=x K / 2 H$ and $\omega=v K / u H$ along the balanced growth path, and define $s^{*}$ as the value of the variable $s$, discounted hy its long-run growth rate, along the halanced growth path. The first-order conditions, evaluated along the balanced growth path, can be expressed as follow's:

$$
\begin{aligned}
& \frac{W^{*}}{1-\theta}=\lambda^{\cdot} C^{\bullet}-v^{*}\left[\frac{C^{\bullet}}{\left(1-v^{\bullet}-x^{\bullet}\right) K^{*}}-\frac{\theta}{\eta \gamma}\right] \\
& -\frac{\dot{\lambda}}{\lambda}=\alpha A \omega^{\alpha-1} \\
& -\frac{\dot{\mu}}{\mu}=(1-\beta) B \sigma^{\theta}-\delta+\left[\frac{\nu^{\bullet}}{\mu^{\bullet}} \frac{W^{\bullet}}{H^{\bullet}}\left[1+\beta\left(\frac{1}{z^{\bullet}}+B \sigma^{\theta}\right)\right]+\frac{\xi^{\bullet}}{\mu^{\bullet} H^{\bullet}} \frac{\gamma}{1-\gamma} \frac{1-\beta}{\beta} \frac{1-u^{\bullet}-z^{\bullet}}{z^{\cdot 2}}\right]
\end{aligned}
$$




$$
\begin{aligned}
& \lambda^{*}\left(\alpha A K^{*} \omega^{\alpha-1}-\frac{\eta C^{*}}{1-\nu^{*}-x^{*}}\right)=\frac{v^{*}}{1-v^{*}-x^{*}}\left[\frac{C^{*}(1+\eta \gamma)}{\left(1-\nu^{*}-x^{*}\right) K^{*}}-1\right]-\frac{\xi^{*}}{x^{*}}
\end{aligned}
$$

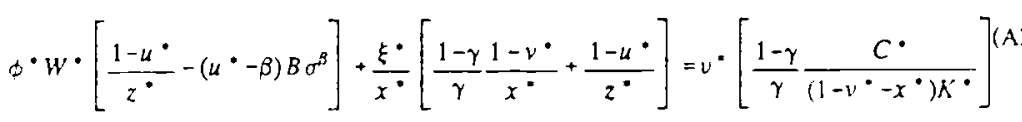

$$
\begin{aligned}
& \lambda \cdot\left[\frac{\eta(1-\gamma) C^{*}}{\left(1-u^{*}-z^{*}\right)(1-\alpha) H^{*} \omega^{\alpha}}\right]=\frac{\phi^{*} W^{*}}{1-u^{*}-z^{*}}\left[1-\left(1-\beta-z^{*}\right) B \sigma^{8}\right]+ \\
& +\frac{\xi^{*}}{z^{*}} \frac{\gamma}{1-\gamma} \frac{1-\beta}{\beta}+\frac{v^{*}}{1-u^{*}-z^{*}}\left[\frac{\eta(1-\gamma) C^{*}}{\left(1-\nu^{*}-x^{*}\right) K^{*}}-\frac{1-\gamma}{\gamma}\right] \\
& \lambda^{*}(1-\alpha) A H^{*} \omega^{\alpha}=\mu^{*}(1-\beta) B H^{*} \sigma^{\beta}+\frac{\xi^{*}}{z^{*}} \frac{\gamma}{1-\gamma} \frac{1-\beta}{\beta} \frac{1-u^{*}-z^{*}}{z^{*}} \cdot \phi^{*} \cdot W^{\bullet}\left[\frac{\beta}{z^{*}}+B \sigma^{3}\right\}
\end{aligned}
$$

Comparing these FOC with those of the consumer problem along the balanced grouth path, it is immediate from (14) and (A22) that the long-run tax rate on capital has to be zero. This also implies that the LHS of equation (A24) is equal to zero (see equation (A11)). Evaluating equations (A23)-(A27) we then obtain that the three multipliers $v^{*}, \phi^{*}$ and $\xi^{*}$ are equal to zero. From equations (A26) and (A12) we conclude that the optimal tax on human capital is zero as well. The intuition for the fact that the three constraints imposed by the consumer's optimality conditions on the government's bchavior are not bindins in the long run $\left(v^{*}=\phi^{*}=\xi^{*}=0\right)$ is the following. In the long run, $\tau^{X}=\tau^{H}=0$ : hence all distortions are eliminated and the consumer's optimality constraints 10 not restrict the government's resource allocation choice.

The proof of optimality for the case in which $\beta=0$ and for wher leisure is "raw' time" is perfectly analogous, and is available from the authors upon request.

\section{A4. Optimal taxation when $\beta=0$ and there is no leisure}

In this case the optimal taxation solution requires a limit on the tax rate on physical capital, since the latter has no alternative uses. The constraint associated with this limit will be binding in the initial periods, but not in the long run -- if it were, agents would devote no resources to capital accumulation.

The government's problern can be formulated as follows: 


$$
\begin{aligned}
& \operatorname{Mar}(1+\psi) \int_{0}^{\infty} \frac{C_{t}^{t-\sigma}}{1-\sigma}-\psi \hat{w}_{0}^{t} \\
& \text { s.t. } \\
& \dot{K}_{t}=A K^{\alpha}(u H)^{1-\alpha}-C_{t}-G_{t}-\delta K_{t} \\
& H_{t}=B\left(1-u_{t}\right) H_{t}-\delta H_{t} \\
& 0=\gamma_{t}\left[C_{t}+\frac{1}{\theta}(\rho+\delta) C_{t}\right]
\end{aligned}
$$

where the last condition ensures that $\tau^{\mathrm{K}} \leq 1$.

The first order conditions, evaluated along the bulanced growth path, vidt:

$$
\begin{gathered}
\lambda \cdot(1+\psi)=C^{\cdot-1} \\
-\frac{\dot{\lambda}}{\lambda}=\alpha A\left[\frac{K^{\cdot}}{u^{*} H^{\cdot}}\right)^{\alpha-1}-\delta \\
-\frac{\dot{\mu}}{\mu}=B-\delta \\
\lambda \cdot(1-\alpha) A\left(\frac{K^{*}}{u^{*} H^{*}}\right)^{\alpha}=\mu^{\cdot} B
\end{gathered}
$$

where a star indicates the value of a variable along the balanced growth path, discounted by its long-run growth rate. Equating (30) and (31) we determine the long-run capital/abor ratio in production. Comparing it with the one resulting from the consumer's optimality conditions (cquation (28) with $v=1$ ) proves that the long-run tax on physical capital should be equal to zero. Evaluation of the consumer's FOCs along the balanced growth path slows that the tax on labor income is non distortionary in the long run: as shown in Propositions 3 and 5, the labor tax does not affect the growth rate and the allocation of factors. It follows that along the balanced growth path the tax on labor should be positive. 
BIBLIOGRAPHY

Barto, Robert (1990), "Government Spending in a Simple Model of Endogenous Growth", Joumbai of Political Economy 98, part 2, October, S103-S125.

Barro, Robert and Xavier Sala-j-Martin (1994), Economic Growth, Mc Graw-Hill, forthcoming.

Becker, Gary S. (1965), "A Theory of the Allocation of Time", Economic Joumal 75, September, 493-517.

Benhabib, Jess and Andrés Velasco (1994), "On the Economics of Fiscal Populism in an Open Economy", mimeo, New York University, Septenber.

Benhabib, Jess, Richard Rogerson and Randal! Wright (1991), "Homework in Macroeconomics: Househoid Production and Aggregate Fluctuations", Joumal of Polisical Economy 99, December 1991, 1166-87.

Ben Porath, Yoram (1967). "The Production of Human Capital and the Life-Cycle of Earnings", Journal of Polisical Economy 75, No.4 part 1, August, 352-365.

Buiter, Willem and Kenneth KJetzer (1991), "Persistent Differences in National Productivity Growth Rates with a Common Technology and Free Capital Mobility: the Roles of Public Debt, Capital Taxation and Policy cowards Iuman Capital Formation", Journal of the Japanese and Internarional Economies 5, December. 325-53.

Bull, Nicholas (1993a), "When All the Optimal Dynamic Taxes Are Zero", Federal Reserve Board Working Paper no. 137, July.

Bull, Nicholas (19936), "Technical Appendix to When All the Optimal Dynamic Taxes Are Zero", Federal Reserve Board Working Paper no. 138, July.

Caballe, Jordi and Manuel S. Santos (1993), "On Endogenous Growth with Physical and Human Capital", Joumal of Political Economy 101, December, 1042-67.

Chamley, Christophe (1985), "Efficient Taxation in a Stylized Model of Intertemporal General Equilibrium", Insemarional Economic Review 26, No.2, June. 451-468.

Chamley, Christophe (1986), Optimal Taxation of Capital Income in General Equilibrium with Infinite Lives", Econometrica 54, May, 607-22.

Chari, V.V., Lawrence J. Christiano and Patrick J. Kehoe (1991), "Optimal Monetary and Fiscal Policy in a Business Cycle Model", Joumal of Mone\%, Cretit and Banking 23, August (part 2), 519-39.

Chari, V.V., Lawrence J. Christiano and Parrick J. Kehoe (1993), "Optimal Fiscal Policy in a Business Cycle

Model", Federal Reserve of Minneapolis Staff Report no. 160, July.

Correia, Isabel (1992), "Dynamic Optimal Taxation in Small Open Economies", mimeo, Bank of Portugal.

Corsetti, Giancarlo (1992), "Government Spending, Risk and Wealth Allocation in a Simple Model of Endogenous Growth", Universita di Roma, mimeo. 
Greenwood, Jeremy and Zvi Hercowitz (1991), "The Allocation of Capital and Time over the Business Cycle", Joumal of Political Economy 99. December, 1188-1214.

Heckman, James (1976), "A Life-Cycle Model of Eamings, Learning, and Consumption". Joumal of Political Economy 84, August, S11-S44

Jones, Larry E.. Rodolfo E. Manuelli and Peter E. Rossi (1993a), "Optimal Taxation in Models of Endogenous Growth", Juurnal of Political Economy 101, June, 485-517.

Jones, Larry E., Rodolfo E. Manuelli and Peter E. Rcssi (1993b), "On the Optimal Taxation of Capital Income". NBER Working Paper no. 4525. November.

Judd, Kenneth L. (1985), "Redistributive Taxation in a Sinple Perfect Foresight Model", Journal of Public Economics 28, October, 59-83.

Judd, Kenneth L. (1987), "The Welfare Cost of Factor Taxation in a Perfect Foresight Model", Joumal of Political Economy 95, No.4, 675-709.

Judd, Kenneth L. (1990). "Optima Taxation in Dynamic Stochastic Economies", mimeo, Stanford University.

Kin, Se-Jik (1992) Taxes, Growth and Welfare in an Endogenous Growth Model, Ph.D. Dissertation, University of Chicago.

King. Rober G. (1991), "Observable Implications of Dynamicaly Optimal Taxation", University of Rochester Working Paper, August.

King. Robert G., Charles I. Plosser and Sergio T. Rebelo (1988), "Production, Growth and Business Cycles: I. The Basic Neoclassical Model", Journal of Monetary Economics 21, 195-232.

King, Robert G. and Sergio Rebelo (1990), 'Public Policy and Economics Growth: Developing Neoclassical Implications", Joumal of Political Economy 98, No.5, part 2, October, S126-S150.

Lucas, Robert E. Jr. (1988), "On the Mechanics of Ecunomic Development", Joumal of Monetary Economics $22,3-42$.

Lucas, Rober E. Jr. (1990), "Supply-Side Economics: an Analytical Review", Oxford Economic Papers 42, 293-316.

Lucas, Rober E. Jr. and Nancy L. Stokey (1983), "Optimal Monetary and Fiscal Policy in an Economy without Capita", Joumal of Monesary Economics 12, July'. 55-93.

Milesi-Ferreti. Gian Maria and Nouriel Roubini (1994a), "Taxation and Growth in Open Economies", International Monetary Fund Working Paper no. 94/77, July.

Milesi-Ferretti, Gian Maria and Nouriel Roubini (1994b), "Taxation and Endogenous Growth: On the Effects of Consumpion Taxes", in progress. 
Mulligan, Casey and Xavier Sila-i-Martin (1993), "Transitional Dynamics in Two-Sector Models of Endogenous Growth", Quarterty Joumal of Economics CVII, August, 739-73.

Ruzin, Assaf and Chi- $W_{a}$ Yuen (1992), "Convergence in Growth Rates: the Role of Capital Mobility and International Taxation", NBER Working Paper no, 42:4,

Rebelo, Sergio (1991), Long-Run Policy Analysis and Long-Run Growth", Journal of Political Eionony 99, June, $500-521$.

Rebelo, Sergio (1992), "Growth in Open Economies", Carnegie-Rochester Conference Series on Public Policy 36 , July, 5-46.

Romer, Paul (1986), "Ircreasing Returns and Long-Rin Grou'th", Joumal of Potitical Economy: 94, October, 1002-1037.

Roubini, Nouriel and Xavier Sala-i-Martin (1992a), "Financial Repression and Economic Growth", Journal of Development Economics 39, 5-30.

Roubini, Nouriel and Xavier Sala-i-Martin (1992b), "A Growth Model of Inflation, Tax Evasion and Financial Repression", NBER Working Paper No.4062, May.

Stokey, Nancy L. and Sergio Rebelo (1993), "Growth Effects of Flat-Rate Taxes". NBER Working Paper no.4426, August.

Tanzi, Vito and Howell H. Zee (1993), "Time Constraint in Consumption and Savings Behavior", Joumal of Public Economics 50, 253-259.

Trostel, Phillip (1993), "The Effect of Taxation on Human Capital", Journal of Political Econonry 101, April, $327-50$.

Yuen. Chi-Wa (1990), "Taxation, Human Capital Accumulation and Economic Growth", mimeo, University of Chicago.

Zhu, Xiadong (1992), "Oprimal Fiscal Policy in a Stochastic Growth Model", Joumal of Economic Theory 58, December, $250-89$. 


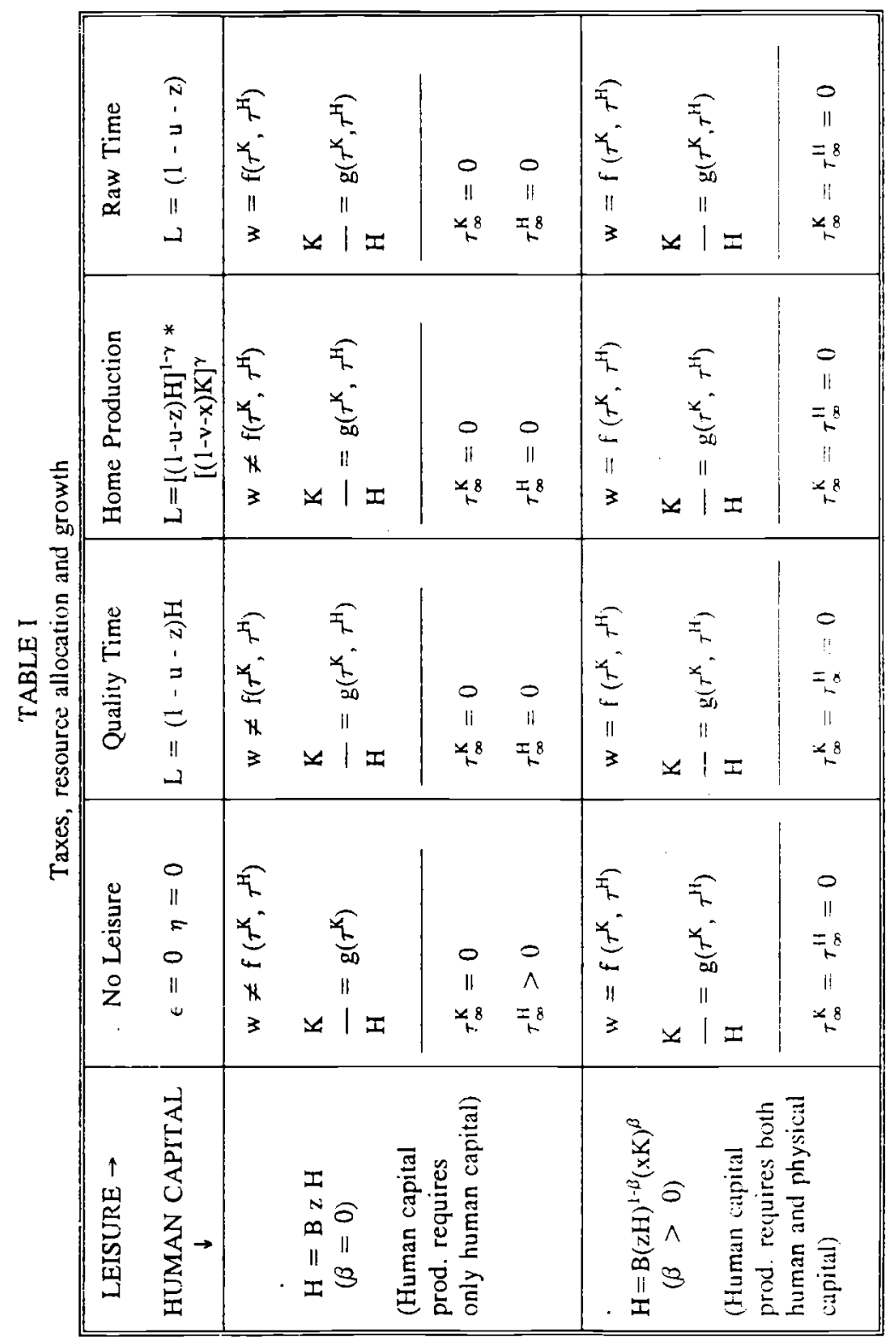

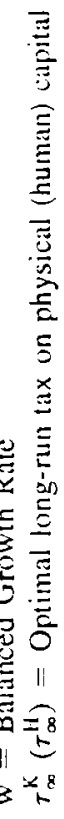

